\title{
Leg ulcer in lepromatous leprosy - Case report ${ }^{\star}$
}

\author{
Tania Rita Moreno de Oliveira Fernandes ${ }^{1}$ \\ Ramon Rodrigues de Macedo Lopes ${ }^{1}$
}

\author{
Talita Suzany Siqueira dos Santos ${ }^{2}$
}

DOI: http://dx.doi.org/10.1590/abd1806-4841.20164149

\begin{abstract}
In Brazil, leprosy is a widespread infectious and contagious disease. Clinicians and specialists view leprosy broadly as a systemic infection, since, in its manifestations, it mimics many conditions, such as rheumatic, vascular, ENT, neurological and dermatological diseases. There are few studies that characterize the factors associated with ulcers in leprosy. These injuries should be prevented and treated promptly to avoid serious problems like secondary infections, sepsis, carcinomatous degeneration and amputations. We describe a patient with ulcers on his legs, involving late diagnosis of lepromatous leprosy. Keywords: Leg ulcer; Leprosy; Leprosy, Multibacillary
\end{abstract}

\section{INTRODUCTION}

According to the World Health Organization's (WHO) epidemiological bulletin from August $27^{\text {th }}, 2010$, Brazil has the second highest number of leprosy cases (HD) worldwide (37,610 cases), concentrating $93 \%$ of cases in the Americas. The North, Northeast and Midwest are the most affected regions, with high detection rates. ${ }^{1}$ Even in endemic areas, such as northeastern Brazil, diagnosis of this disease is neglected, most likely because general practitioners and specialists are unfamiliar with many of the typical signs and symptoms.

The ulcers in leprosy occur by direct action of Mycobacterium leprae on the peripheral nerves, with changes in the sensory, autonomic and motor fibers (neuropathic ulcers). ${ }^{2}$ Less frequently, it is due to direct invasion of bacilli in the vascular endothelium, causing vasculitis, cutaneous necrosis and ulcers. ${ }^{3}$

The authors report a case of classic lepromatous leprosy (HDV), treated for about 2 years as stasis ulcers, in witch he diagnosis of leprosy had not been considered by clinicians nor angiologists, despite the endemicity of the region.

\section{CASE REPORT}

A 36-year-old woman, born and raised in Juazeiro - BA, presented with edema and paresthesia on the lower limbs two years ago, along with infiltration on the face and hoarseness. Two months after the initial manifestations, there were ulcers on the lower limbs. She attended medical appointments and was sent to the vascular surgeon, because of ulcers on the lower limbs - diagnosed as stasis ulcers. Topical treatment was maintained, without clinical improvement. Because of the morbidity resulting from ulcerative lesions, the patient began receiving disability compensation from the Social Security Institute. On physical examination, there was: hoarseness, characteristic infiltration on the face, affecting the eyebrows and ears, madarosis, swelling on the hands and lower limbs, large ulcers on the anterior and median sizes of both legs, in addition to desquamation of the feet (Figures 1, 2 and 3). There were no palpable peripheral nerves. Laboratory tests entailed: normal blood count, urinalysis, liver and kidney function tests. The intradermal smear examination was positive, with the presence of isolated and globi bacilli (IB: 3.2) (Figure 4). Treatment involved multibacillary multidrug therapy and different topical medication for ulcers. After approximately 70 days, she saw an improvement. After 10 months of starting the treatment, the patient experienced hoarseness and almost complete healing of ulcers on the lower limbs, but with stigmatizing effects on the face caused by the fall of the nasal pyramid, as confirmed by computed tomography of the face (Figures 4,5 and 6).

\section{DISCUSSION}

With a high prevalence in Brazil, leprosy determines changes in the peripheral nervous system and skin. Neural damage leads to changes in sensitivity, changes in tropism and motor function, which predisposes to ulceration.

Received on 27.10.2014.

Approved by the Advisory Board and accepted for publication on 03.02.2015.

* Trabalho realizado na Universidade Federal do Vale do São Francisco (UNIVASF) - Petrolina (PE)- Brazil.

Financial Support: None.

Conflict of Interest: None.

Universidade Federal do Vale do São Francisco (Univasf) - Petrolina (PE)- Brazil.

Universidade Federal de Alagoas (UFAL) - Maceió (AL)- Brazil.

(C)2016 by Anais Brasileiros de Dermatologia 


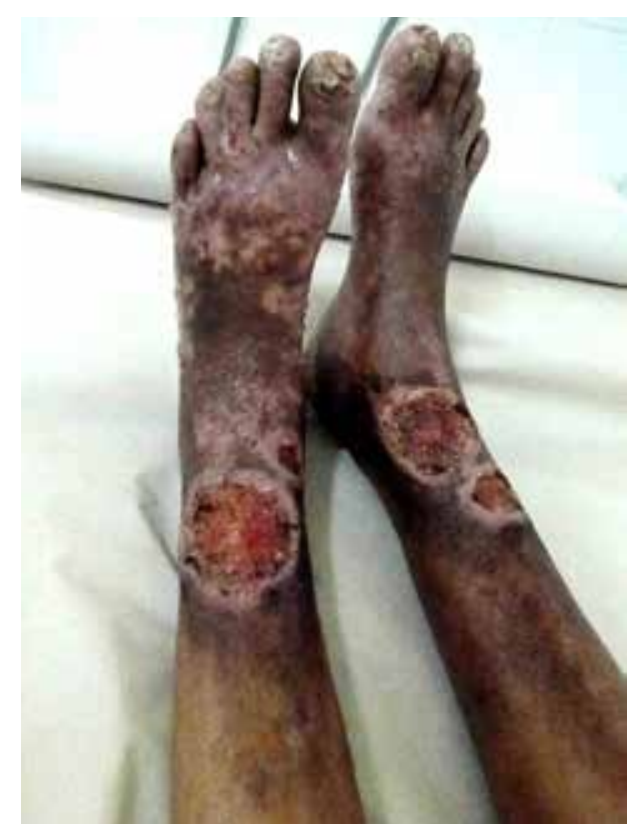

Figure 1:

Large ulcers on the legs over hyperpigmented and desquamated skin, and ungual alterations

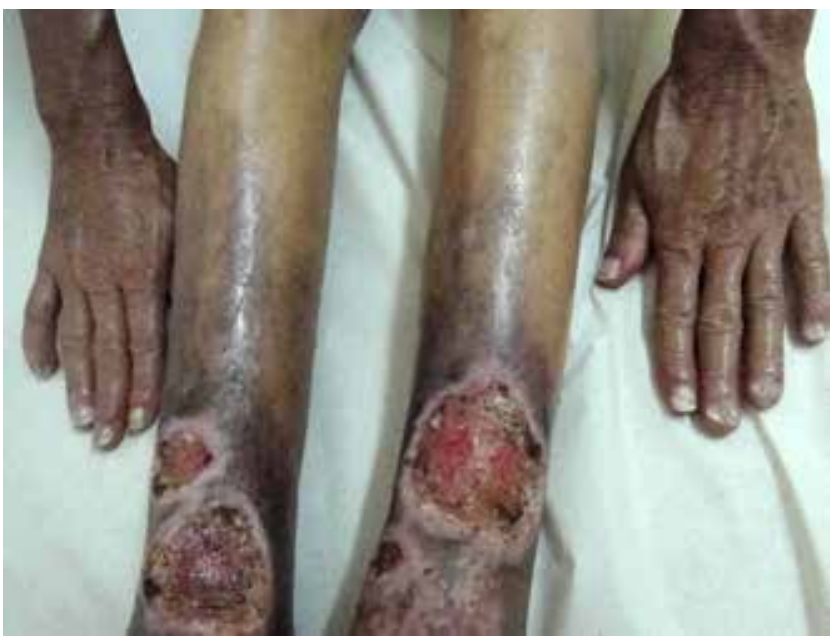

FigurE 2: Large ulcers on the legs and swelling of the hands. Note the trophic changes on the legs and hands

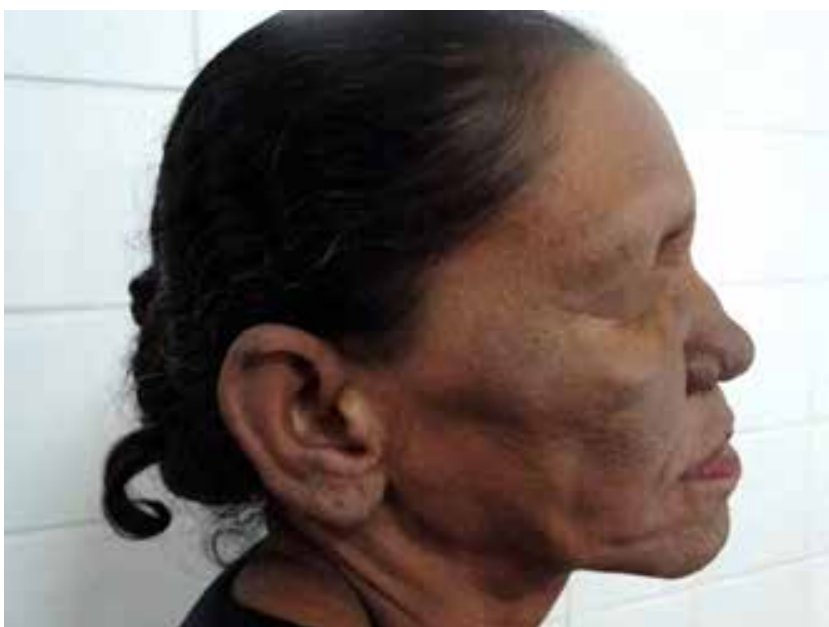

Figure 3: Presence of madarosis, nasal deformity and ear infiltration

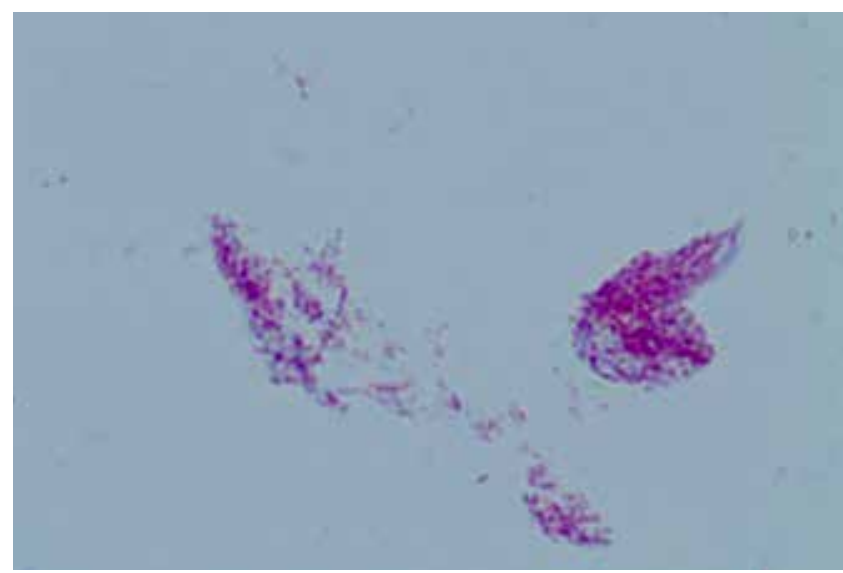

Figure 4: Smear by intradermal shaving. Ziehl-Neelsen staining Presence of globias and macrophages containing large amounts of bacilli inside the cytoplasm. Image with 400X magnification.

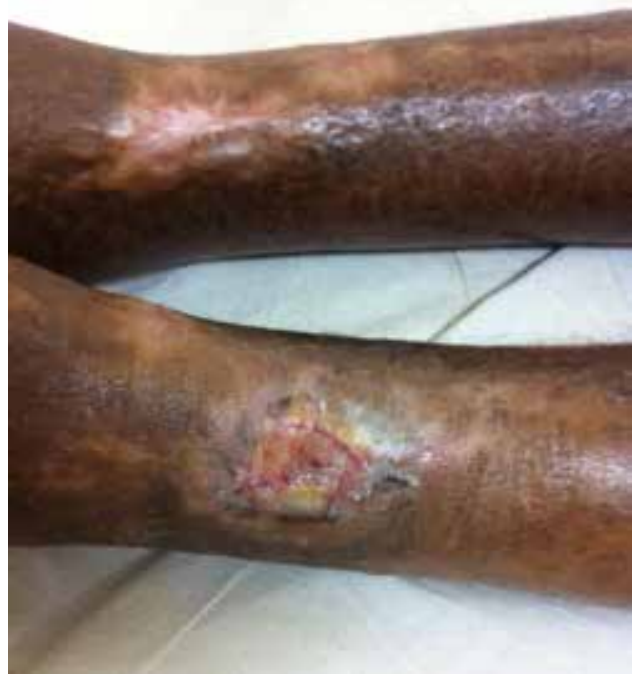

Figure 5:

Marked improvement of the ulcers and the trophic skin signs after 10 months of multidrug therapy

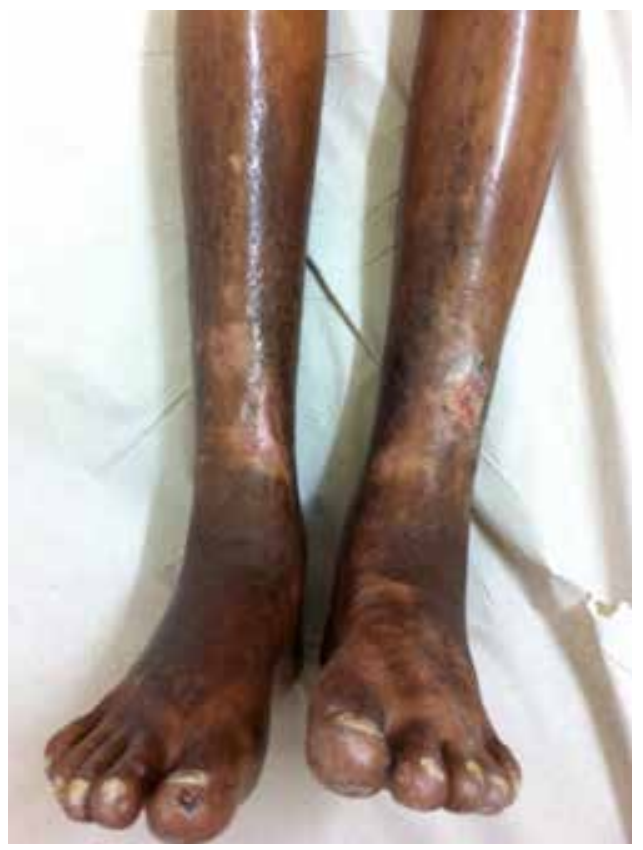

Figure 6:

Marked improvement of the ulcers after 10 months of specific drug therapy 
These chronic, neuropathic, ulcers have very peculiar characteristics, such as circular edges, erythematous surfaces. They occur in high pressure areas such as the feet, and less commonly, on the legs, thighs and upper limbs. ${ }^{2}$

Patients with borderline tuberculoid leprosy have a higher risk of chronic ulcers, followed by individuals with lepromatous and borderline lepromatous forms. ${ }^{4}$

Another mechanism that provokes ulcers in leprosy is the direct invasion of the vessel walls and endothelium by bacilli, determining granulomatous local reactions of the tuberculoid type, vasculitis, cutaneous necrosis and ulcerations. ${ }^{5}$ In lepromatous leprosy, both diffuse infiltration and hansenomas can ulcerate, due to the inflammatory infiltrate, containing large amounts of bacilli within macrophages. In turn, this can cause obstruction of superficial veins and may lead to lepromatous panfeblite. In blood vessels, bacilli can provoke granulomatous reactions, and bacilli are found in macrophages, the endothelium and vascular lumen in the peripheral circulation. These injuries can lead to severe consequences, such as osteomyelitis and amputation. ${ }^{6}$

Leprosy patients may also present chronic venous insufficiency, like many other patients patients without leprosy. If associated with other comorbidities, leads to the formation of varicose veins, edema, diffuse pigmentation, on or off the post-phlebitic syn-

\section{REFERENCES}

1. Who.int [Internet]. World Health Organization. Weekly epidemiological record: Global leprosy situation, 2010. 35. ed. Geneve: World Health Organization, 2010. 12 p. [cited 2014 Oct 25] Available from: <http://www.who.int/wer/2010/ wer8535. pdf?ua $=1>$.

2. Andrade PJS, Oliveira P CBF, Messias, SSND, Nery JAC. Ùlceras indolentes : Hanseníase como diagnóstico diferencial. Hansen Int. 2013; 38:154.

3. Ribeiro SLE, Guedes EL, Pereira HLA, Souza LS. Manifestações sistêmicas e ulcerações cutâneas da hanseníase: diagnóstico diferencial com outras doenças reumáticas. Rev Bras Reumatol 2009;49:623-9.

4. Muñoz AML, Guimarães MG, Nery JAC. Carcinoma escamocelular em úlcera de Marjolin. Revista SPDV. 2013;71:119-122

5. Souza LWF. Reações hansênicas em pacientes em alta por cura pela poliquimioterapia. Rev Soc Bras Med Trop. 2010;43:737-9.

6. Teixeira Junior GJA, Silva CEF, Magalhães V. Aplicação dos critérios diagnósticos do lúpus eritematoso sistêmico em pacientes com hanseníase multibacilar. Rev Soc Bras Med Trop. 2011;44:85-90.

7. Oda R M, Galan NGA, Opromolla DVA. Úlceras de perna na hanseníase. In: Opromolla DVA, Baccarelli R, editores. Manual de prevenção de incapacidades e Reabilitação em Hanseníase. Bauru: Instituto Lauro de Souza Lima, 2003. p 130-133.

8. Gomes FG, Frade MAC, Foss NT. Úlceras cutâneas na hanseníase: perfil clínicoepidemiológico dos pacientes. An Bras Dermatol. 2007;82:433-7

9. Palheta Neto FX, Silva Filho M, Pantoja Junior J MS, Teixeira LLC, Rafaela Vale de Miranda RV, Palheta A C P. Principais queixas vocais de pacientes idosos póstratamento para hanseníase Braz J Otorhinolaryngol. 2010;76:156-63. drome. These ulcers have different morphologies and may impair large areas. In the ones that also exhibit change in blood circulation, necrotic areas are observed on their bottom and often tendons exposure. ${ }^{7}$

Since the patient experienced a resolution of ulcers following specific polychemotherapy, unlike the 2-year treatment with angiologists, neurotrophic changes are accepted as the main mechanism, typical of lepromatous leprosy, combined with a high bacterial load and endo-vascular phenomena. ${ }^{8}$

The patient's hoarseness from the time of diagnosis is due to the direct invasion of bacilli in the superior airways. ${ }^{9}$ Generally, oropharynx lesions are followed by nasal lesions (as presented by this patient). The following parts of the mouth are affected: the lips, palate, uvula, gums, tongue and anterior pillars. Furthermore, the nasopharynx and palatine tonsils can also be affected. ${ }^{9}$

This case draws attention to the severity of the ulcer and the involvement of the upper airways.

We noted that the diagnosis of leprosy had not been considered in this case, despite the typical clinical situation, the easy access to complementary diagnostic examination and although the patient's region of origin is at an increased risk of leprosy.

It is essential to invest in medical education and postgraduate qualifications so that late diagnoses such as this no longer perpetuate the chain of transmission. $]$

\author{
MAILING ADDRESS: \\ Tânia Rita Moreno de Oliveira Fernandes \\ Av. José de Sá Maniçoba, s/n \\ Centro \\ 56360-205 - Petrolina - PE \\ Brazil \\ E-mail: trmofernandes@gmail.com
}

How to cite this article: Fernandes TRMO, Santos TSS, Lopes RRM. Leg ulcer in leprosy lepromatous - Case report. An Bras Dermatol. 2016;91(5):673-5. 